\title{
QUALITY OF WORK AS A CHALLENGE FOR MODERN MANAGEMENT OF HUMAN RESOURCES IN RELATION TO EMPLOYEES FROM Z-GENERATION
}

doi: 10.2478/cqpi-2019-0013

Date of submission of the article to the Editor: 10/04/2019

Date of acceptance of the article by the Editor: 21/05/2019

\author{
Elżbieta Robak - orcid id: 0000-0001-8936-4617 \\ Anna Albrychiewicz-Słocińska - orcid id: 0000-0002-7245-4461 \\ ${ }^{1}$ Czestochowa University of Technology, Poland
}

\begin{abstract}
The goal of the paper is to present chosen problems of management of ZGenerations' employees connected with the quality of work. The characteristics of the youngest employees revealing their specific attitude towards work and expectations toward employers as well as lack of competences show particular importance of the issue of quality of work in relation to this generation.

Nowadays, focusing employees on the quality of work does not mean only precise implementation of strictly defined tasks, because this type of performed work can be ensured by the increasingly widespread automation and robotization of workplaces. Taking up the issues of challenges which for the contemporary human resource management is the quality of working conditions, in relation to the representatives of the Z- generation (Gen Z), paper presents the results of researches and reports illustrating the specificity of these young employees on the labor market. The article attempts to analyze the functioning of the youngest employees and showing instruments by means of which the managers of organizations can shape the involvement of these generation and thus improve the quality of their work.
\end{abstract}

Keywords: Z- generation, quality of work, human resources management,

\section{INTRODUCTION}

The quality of work is a wide concept and in the subject literature, researches and reports it is recognized in various ways. Among the factors which describe the quality of work there are both hard socio - economical factors and subjective criteria of assessment of work environment. In the following essay authors made an attempt to analyze chosen factors about quality of work according to Z-Generation. This generation, still little represented in the labor market is already a particular challenge for human resource managers. Only a little number of reports devoted to this generation is available and these which are possible to get accustomed with signalize the dissimilarity of attitudes and behaviors of the representatives of the Z-Generation. What is more, it should be underlined that simultaneously with entering on labor market of this generation there are dynamic changes in the work sphere itself. It 
considers both technical, technological changes, changes about time and workplace organization, conditions and forms of employment as well as well- being and work- life balance issues. The goal of this paper is to show chosen problems of employees' management from Z- Generation connected with the quality of work about results of researches and international reports.

\section{CHARACTERISTICS OF Z- GENERATION AGAINST OTHER GENERATIONS OF EMPLOYEES}

On a modern labor market there are representatives of several employees' generations. Starting with still professionally active employees from the Baby Boomers' Generation, through dominant X- Generation and Y- Generation, to the youngest people who represent Z- Generation. In the subject literature a differentiation is visible which concerns both terminology related to the naming of these generations, as well as delimitation between individual generations. (Bencsik et al., 2016; Bejtkovský, 2016).

According to some authors it is the most often accepted, that Z- Generation consists of people who were born after 1995, but still some researches include people born after 1990 among this group and in other terms even those who were born in 2000 and later (Dolot, 2018). In descriptions which characterize people from the Gen Z, it is most often emphasized that its representatives have technology "in their blood", which allows them to function efficiently in the virtual world and quickly acquire information. These young people like changes and are considered pragmatists, because they are aware of the inevitable transformations in many spheres of life, including the professional one. They are ambitious, confident and hungry for knowledge. They are looking for a job that will give them opportunities for development. In addition, they can operate in the real and virtual world and switch smoothly from one to the other. Constant access to the Internet, the ability to use many applications, and above all social media networks are needed 24 hours a day. However, it is believed that they have difficulties in direct communication and concentrating longer on one task (O'Boyle et al., 2017). Representatives of Z- Generation need clear information what they are expected to do and feedback how they perform their duties. These young people who grew up in a world being a global village, characterize openness and being direct in expressing their opinions. They are used to provide feedback because if they like something they "like it”, give ratings and express opinions, commenting reality. They are characterized by their inherent multitasking. Generation representatives are able to do several things at the same time and this is in some way natural for them. (Tulgan, 2013; Sidorcuka and Chesnovicka, 2017).

For representatives of Gen Z, new technologies are an immanent element of private and professional life. In this respect, they resemble people from the increasingly dominant Y- Generation. In the accenture report "Gen Z Rising" (Lyons et al., 2017), however, attention was drawn to the differences between these generations. A balance between private and professional life, as well as the pursuit of self-fulfillment, play a very important role for members of $Y$ - Generation (Robak, 2017). In the case of the Gen Z, one can see a shift towards traditional professional values, such as a clear career path and stabilization, as well as the possibility of using the acquired knowledge. Representatives of the Z- Generation have high self-esteem, but also awareness of the importance of constant learning. They expect, above all, possibilities to create career paths and promotion, availability of training, and opportunities for 
long-term development (Singh and Dangmei, 2016; Lazanyi and Bilan, 2017). What really differentiate them from their parents' generation is not only passion for technology, but also assertiveness. Their involvement in the work depends on a similar approach from the employer. It should also be noted that this is a generation that, outside of work, has its passions and activities. Mostly, they are brought up almost stress-free, they often get what they want, they are pampered, so there is no humility in them, they think that everything is due to them.

\section{METHODOLOGY}

Characterizing basic terminological issues concerning the subject discussed in the article, reference was made to the subject literature. But, analyzing the factors which describe quality of work, the desk research method was used ( Bednarowska, 2015) and indicators developed for the OECD and Ipsos research.

The OECD (2014) framework for measuring and assessing job quality considers three objective and measurable dimensions of job quality:

- Earnings quality captures the extent to which earnings contribute to workers' well-being in terms of average earnings and their distribution across the workforce.

- Labour market security captures those aspects of economic security related to the risks of job loss and its economic cost for workers. It is defined by the risks of unemployment and benefits received in case of unemployment.

- Quality of the working environment captures non-economic aspects of jobs including the nature and content of the work performed, working-time arrangements and workplace relationships. These are measured as incidence of job strain characterised as high job demands with low job resources.

While Ipsos raport (Duffy et al., 2018) looking across the findings - on everything from health, risk-taking behaviour, social action, technology use, attitudes to privacy, political views, optimism for the future, trust in institutions and people, social attitudes, sexuality and many other subjects.

The authors adopted a general hypothesis assuming that human resource managers wanting to shape the involvement of employees from the $Z$ Generation and improve the quality of their work must take into account their specific attitudes and expectations related to work.

\section{JOB QUALITY AND THE GEN Z - RESULTS AND DISCUSION}

Nowadays, people devote to work not only the main part of their day time but also a main part of their lives. Work influences subjective feeling of life satisfaction or wellbeing. It's no wonder that the attention of researchers, politicians, employers and the employees themselves is caught by the broadly understood quality of work. The quality of work has been examined for several decades by OECD. In reports of this organization it was assumed that the factors describing the quality of work include: quality of earnings, safety of the labor market and quality of the work environment (analyzed mainly through the job strain) (Figure 1). 


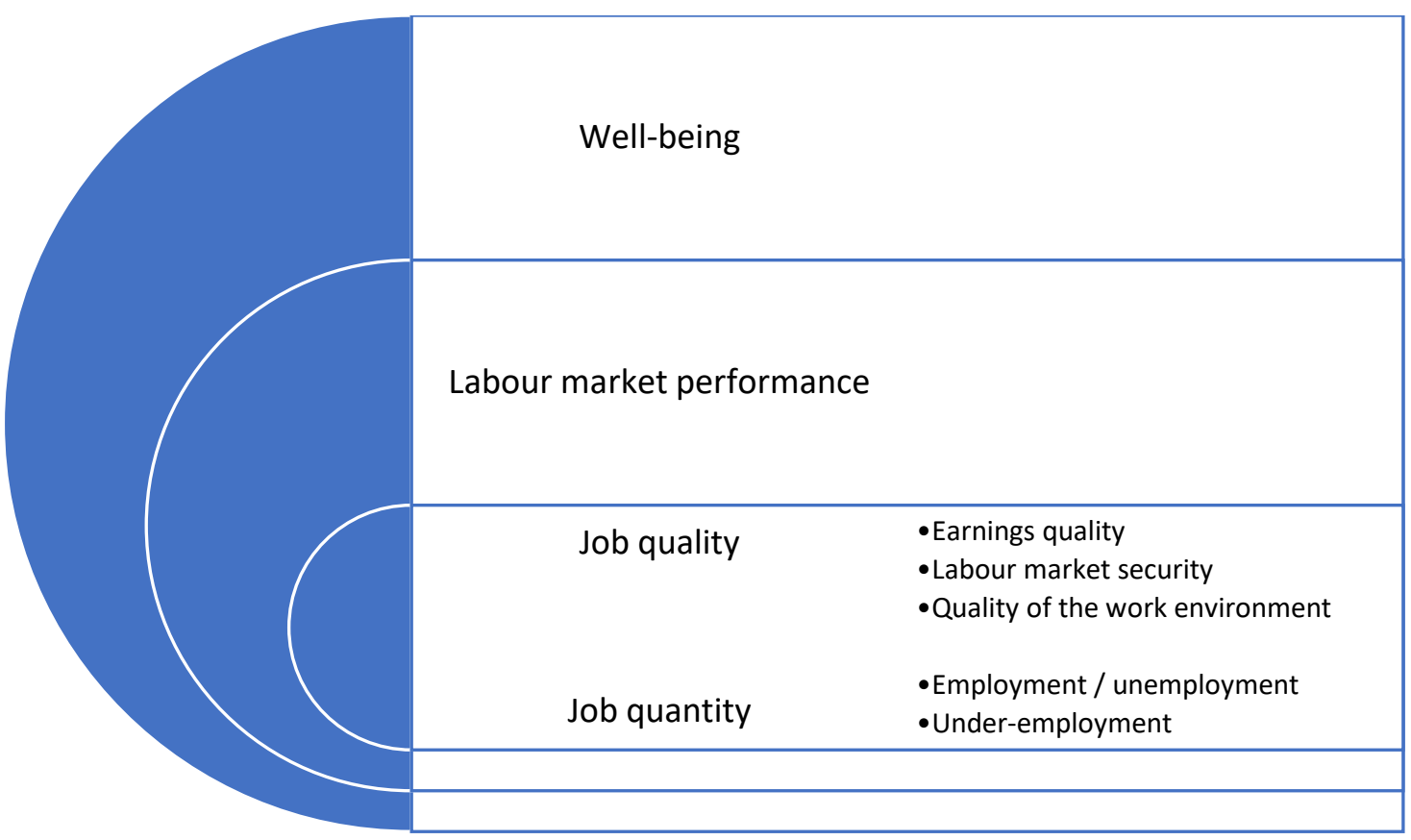

Fig. 1. Job quantity, job quality and well-being

Source: (Cazes, et al., 2015).

The elements included in the aggregated job strain index are presented in Table 1.

Table 1.

Job demands, job resources and job strain

\begin{tabular}{|c|c|c|c|}
\hline \multicolumn{4}{|c|}{ Job strain, as the result of ... } \\
\hline \multicolumn{2}{|r|}{... too many job demands } & \multicolumn{2}{|c|}{$\ldots$ and too few job resources } \\
\hline $\begin{array}{l}\text { Time } \\
\text { pressure }\end{array}$ & $\begin{array}{l}\text { Work usually more than } 50 \text { hours per } \\
\text { week } \\
\text { Difficult to take an hour or two off during } \\
\text { working hours for personal or family } \\
\text { matters } \\
\text { Work at very high speed and to tight } \\
\text { deadlines }\end{array}$ & $\begin{array}{l}\text { Work } \\
\text { autonomy } \\
\text { and learning } \\
\text { opportunities }\end{array}$ & $\begin{array}{l}\text { Can choose or change the order of } \\
\text { tasks } \\
\text { Can choose or change methods of } \\
\text { work } \\
\text { Job involves learning new things } \\
\text { Employer 3provided training or on- } \\
\text { the-job training }\end{array}$ \\
\hline $\begin{array}{l}\text { Physical } \\
\text { health risk } \\
\text { factors }\end{array}$ & $\begin{array}{l}\text { Tiring and painful positions } \\
\text { Carrying or moving heavy loads } \\
\text { Exposed to vibrations from hand tools, } \\
\text { machinery } \\
\text { Exposure to high noise } \\
\text { Exposure to high or low temperature }\end{array}$ & $\begin{array}{l}\text { Good } \\
\text { workplace } \\
\text { relationships }\end{array}$ & $\begin{array}{l}\text { Feel "at home" at work and have very } \\
\text { good friends at work }\end{array}$ \\
\hline
\end{tabular}

Source: (Cazes, et al., 2015).

The report OECD (2014) presents a picture of European countries where a ratio which establish the quality of work was and still is to a large extent shaped by the 2008 economic crisis. Among OECD countries Australia, Austria, Denmark, Finland, Germany, Luxeburg, Norway and Switzerland are the best performers, they do well in at least two of the three dimensions of job quality. Estonia, Greece, Hungary, Italy, Poland, Slovak Republic, Spain and Turkey do relatively badly in two or all three dimensions of job quality. Moreover none of these performs very well in at least one of the mentioned indicators.

With regard to the earnings quality factor, changes are observed in most OECD countries. Due to the global crisis, the unemployment and living costs increased significantly, however, the salaries remained at a similar level. This situation has already improved in most countries, hence the increase in the value of the earnings quality factor. The same applies to the uncertainty factor in the labor market, which is 
improving after years of crisis. However, when analyzing the values of indicators of the quality of the work environment, there were no such direct correlations with the economic situation. In some countries as a result of a crisis those employees who were able to keep their work positions they reported a significant improvement of work conditions, while in other countries the decline in the quality of the work environment has also progressed following the progressive decreases in the two aforementioned indicators. In the light of the analysis of labor quality indicators, it seems that the best way to deal with the results of the crisis was presented by Germany, and worst by Greece. In other countries, the impact of the crisis was different with respect to individual indicators.

Another OECD report (Zwart and Baker, 2018) signalizes that there is a growing number of people with low skills which means that young people who enter a labor market are not educated and sometimes they even show deficiencies in basic skills conditioning their daily functioning (conversion ability, reading comprehension skills). It is a rising group of labor market's participants, but, it should be seen that still representatives of the youngest generations are better educated than representatives of Baby Boomers' and X-Generation. The disgraceful exception here is the UK and the US where the indicators of people with deficits in basic skills are comparable in both groups of 16-24 and 55-65 years. The growing percentage of this group of employees, unfortunately, has a strong negative impact on productivity and is closely related to low quality of work. The presented situation leads to the conclusion that young, not qualified employees feel uncertainty on a labor market and unfortunately, it has an impact on their level of wellbeing. This is confirmed by the results of the research published in the next OECD report (Hijzen and Menyhert, 2016)

In these socio- economical conditions young generation enters into a labor market. It is then worth to focus on attitudes, behaviors and expectation it represents. Understanding them will allow managers to suit work environment and to create Gen $Z$ involvement and productivity. Ipsos report (Duffy et al., 2018) indicates that although the Z- Generation is the first uniform generation in terms of experience (for example representatives of the $\mathrm{Y}$ - Generation, depending on the material situation and the level of economic development of the country experienced differently the influence of modern technologies) do not show radically different characteristics than previous generations. It seems that they represent similar attitudes and behaviors but motives standing beyond them are different. What differentiate Gen Z from predecessors is larger tolerance and liberalization of views on various aspects of social life, such as sexual behavior and gender roles. Majority of them represents sexually neutral attitudes, preferring to abolish gender distinctions, e.g. in relation to clothing, footwear or even gender neutrality of public toilets. Representatives of ZGeneration in the field of gender roles more often make choices that blur the existing divisions between women and men. Women are in bigger extend orientated on coming back to work after a maternity leave, while their partners take over house works. The report underlines that a lot of Gen $Z$ after finishing 18 years, still stay with their parents and are in good relationships with relatives. In comparison with $Y$ Generation, they have better contact with parents and they take their time on conversations with them. They present smaller activity in the area of use of psychoactive substances, sexual activity and criminal behavior. One can wonder whether this is a generation with other, higher moral standards compering with $Y$ generation or they needs associated with this type of activity are satisfied in another 
dimension. A characteristic feature of this generation is the constant presence in the media and cyberspace, perhaps it is the space where there are committed crimes or practice sexual behaviors (less sex more sexting), which are not recorded, however. Gen $Z$ also represents a huge focus on health but, at the same time, physical condition in relation to this generation is indicated by increasing obesity rates, which are most often the result of bad eating habits (eg excess sugar) and lack of physical activity. The results concerning the level of trust among the representatives of the ZGeneration are also interesting. They represent similar lack of trust in terms of institutions, including governmental organizations, but declare high ratio of trust in relationships in the nets as well as in terms of people who they meet in streets. At the same time, they declare a lower level of happiness and with more pessimism than previous generations, they look towards the future, including professional one. This is primarily due to the fact that they are aware of the deteriorating economic and climate conditions and the difficulties they will have to face in the future. They are oriented on success and earning money, but they do not represent a materialistic attitude to life, it is rather the result of a conviction about an uncertain future.

The results of researches confirm the authors' belief that for efficient management of employees from the Z- Generation, it is important to pay attention to the quality of work, with particular emphasis on the quality of the work environment. This factor itself seems to be a dominant element which attracts young people and retains them in organizations. Managers of organizations should take into account the following preferences of representatives of the Gen $Z$ in relation to the work environment:

- flattening the organizational structure: allowing young employees with little experience to feel as equal members of the organization; enabling clear professional development and eliminating pressure to climb the career ladder; facilitating contact with superiors;

- flexible organization of work and working time enabling the implementation of non-professional areas of life;

- including in the workplace the possibility of using devices enabling online access and access to a variety of information and communities;

- the use of modern technologies in communication and professional development processes, e.g. applications that enable learning through games, constant contact with a mentor or a trainer;

- creating a work environment in which they will be able to fully use digital skills, which are their strongest assets;

- preparing superiors for building specific relationships with Gen Z, including: frequent feedback, skillful criticism, taking on the roles of a partner and parent rather than a controller, listening to their ideas and appreciating their opinions (despite young age and limited work experience), positive communication, fairness and honesty of the message;

- taking care of mental and physical hygiene by creating a friendly workplace (eg organization of work space, interior design, opportunities to relax in the workplace, the possibility of eating healthy meals);

- building the image of a socially responsible organization enabling participation in attractive activities (eg volunteering, work for the local community, ecological activities); 
- creating a work environment that integrates Gen Z needs for success and well- being at the same time.

Presented elements which shape the quality of work environment Gen Z should be included and build consciously by people responsible for human resources management. Observed little interest of problems connected with functioning of employees from Z- Generation in a work environment probably results from the fact that they just entering the labor market. However, ignoring these challenges in the long term will result in the organization's difficulties in attracting and retaining these employees at the workplace.

\section{CONCLUSION}

Describing the representatives of the youngest generation on the labor market, it must be emphasized that they have the advantages and disadvantages characteristic for a young age: energy, openness, many bold ideas, and lack of life and professional experience. In the analysis of the functioning of Gen $Z$ in the labor market, one should rely on cyclic studies that allow a comparison between generations at similar stages of life and development. That is why, describing behaviors of representatives of ZGeneration it is difficult to clearly define which features are typical for this generation, and which are only a reflection of young age. Analysis of reports which show Gen Z employees' behaviors in a workplace present that organizations wanting to attract and retain them must adapt to their specifics. It concerns mainly the element of work quality, in particular, the quality of the work environment, which should be included in the activities of the organization, ranging from employer branding, recruitment and selection, onboarding, employee's development, to aspects related to shaping engagement or loyalty. Particular emphasis should be put on building positive relations between superiors with these young employees, since it is mainly up to them that Gen $Z$ assesses the quality of the work environment.

\section{REFERENCE}

Bednarowska, Z., 2015. Desk research - wykorzystanie potencjału danych zastanych w prowadzeniu badań marketingowych i społecznych, Marketing i Rynek, 7, 18-26.

Bejtkovský, J., 2016. The Employees of Baby Boomers Generation, Generation X, Generation $Y$ and Generation $Z$ in Selected Czech Corporations as Conceivers of Development and Competitiveness in their Corporation, Journal of Competitiveness, 8(4), 105-123, DOI: 10.7441/joc.2016.04.07

Bencsik, A., Horváth-Csikós, G., Juhász, T., 2016. $Y$ and $Z$ Generations at Workplaces, Journal of Competitiveness, 8(3), 90-106, DOI: 10.7441/joc.2016.03.06

Cazes, S., Hijzen, A., Saint-Martin, A., 2015. Measuring and Assessing Job Quality: The OECD Job Quality Framework, OECD Social, Employment and Migration Working Papers, 174, OECD Publishing, Paris, https://doi.org/10.1787/5jrp02kjw1mr-en.

Dolot, A., 2018. The characteristic of Generation Z, "e-mentor", 2(74) 44-50, http://dx.doi.org/10.15219/em74.1351.

Duffy, B., Shrimpton, H., Clemence, M., Thomas, F., Whyte-Smith, H., Abboud, T., 2018. Beyond Binary. The lives and choices of Generation Z, Ipsos MORI Social Research Institute, https://www.ipsos.com/ipsos-mori/en-uk/generation-z-beyondbinary-new-insights-next-generation 
Hijzen, A., Menyhert, B., 2016. Measuring Labour Market Security and Assessing its Implications for Individual Well-Being, OECD Social, Employment and Migration Working Papers, 175, OECD Publishing, Paris, https://doi.org/10.1787/5jm58qvzd6s4-en.

Lazanyi, K., Bilan, Y., 2017. Generation Z on the labour market - do they trust others within their workplace? Polish Journal of Management Studies, 16(1), 78-93, DOI: 10.17512/pjms.2017.16.1.07

Lyons, M., Lavelle, K., Smith, D., 2017. Gen Z Rising, Accenture Strategy, https://www.accenture.com/t20170901T080938Z_w__/us-en/_acnmedia/PDF-

50/Accenture-Strategy-Workforce-Gen-Z-Rising-POV.pdf

O'Boyle, C., Atack, J., Monahan, K., 2017. Generation Z enters the workforce. Generational and technological challenges in entry-level jobs, Deloitte Insights, https://www2.deloitte.com/content/dam/insights/us/articles/4055_FoW-GenZ-entrylevel-work/4055_FoW-GenZ-entry-level-work.pdf

OECD, 2014. How good is your job? Measuring and assessing job quality, OECD Employment Outlook 2014, OECD Publishing, Paris, https://doi.org/10.1787/empl_outlook-2014-6-en.

Robak, E., 2017. Expectations of Generation Y Connected with Shaping the Work-Life Balance. The Case of Poland, Oeconomia Copernicana, 8(4), 579-594, DOI: 10.24136/oc.v8i4.35

Sidorcuka, I., Chesnovicka, A., 2017. Methods of Attraction and Retention of Generation Z Staff, International Conference of Central-Bohemia-University (CBUIC) - Innovations in Science and Education, Prague, Czech Republic, 807814,DOI: 10.12955/cbup.v5.1030

Singh, A.P., Dangmei, J., 2016. Understanding the generation Z: the future workforce, South - Asian Journal of Multidisciplinary Studies (SAJMS), 3(3), 1-5, https://www.researchgate.net/publication/305280948_UNDERSTANDING_THE_G ENERATION_Z_THE_FUTURE_WORKFORCE

Tulgan, B., 2013. Meet Generation Z: The second generation within the giant "Millennial" cohort, Rainmaker Thinking Inc., http://www.rainmakerthinking.com/assets/uploads/2013/10/Gen-Z-Whitepaper.pdf

Zwart, S., Baker, M., 2018. Improving productivity and job quality of low-skilled workers in the United Kingdom, OECD Economics Department Working Papers, 1457, OECD Publishing, Paris, https://doi.org/10.1787/14dfd584-en. 